\title{
Detection of Mycoplasma bovis in Pneumonic Calves
}

\author{
Mohammad A. Hamad ${ }^{1 *}$ (D), Zahraa M. AL-Jumaa ${ }^{2}$, Ammar M. Al-Aalim ${ }^{1}$ (D) and \\ Mohammad T. Jaber Mayahi ${ }^{3}$
}

${ }^{1}$ Department of Microbiology, College of Veterinary Medicine, University of Mosul, Mosul, Iraq. ${ }^{2}$ Department of Internal and Preventive Medicine, College of Veterinary Medicine, University of Mosul, Mosul, Iraq. ${ }^{3}$ Forensic DNA Research and Training Center, AL-Nahrain University, Baghdad, Iraq.

\begin{abstract}
Mycoplasma bovis is a major pathogen in respiratory diseases of calves and cause an excessive economic loses. The current study was a goal to diagnoses bovine Mycoplasma and chiefly M. bovis from an outbreak of pneumonia in calves that occurred in Mosul city and mainly in Gogjaly village. Forty-two lung samples were collected from slaughtered and dead pneumonic calves in seven herds of imported calves. Extraction and amplification for DNA were conduct from all samples for diagnosis of Mycoplasma and $M$. bovis by PCR technique. The results have recorded the presence of Mycoplasma in $88.1 \%$ of examined lungs and $M$. bovis was diagnosed in $86.5 \%$ of the positive Mycoplasma samples. Finally the present study is the first local study at the moment which diagnoses Mycoplasma in general and mainly $M$. bovis from pneumonic calves, also according to the results it recommended the use of molecular techniques and principally PCR for the diagnosis of Mycoplasma and M. bovis.

Keywords: Mycoplasma, Mycoplasma bovis, Pneumonia, PCR, Calves.
\end{abstract}

*Correspondence: mahmah1073@gmail.com; 009647511208025

(Received: 25 September 2019; accepted: 05 November 2019)

Citation: Mohammad A. Hamad, Zahraa M. AL-Jumaa, Ammar M. Al-Aalim and Mohammad T. Jaber Mayahi, Detection of Mycoplasma bovis in Pneumonic Calves, J Pure App/ Microbiol., 2019; 13(4):2437-2443. https://doi.org/10.22207/JPAM.13.4.59

(c) The Author(s) 2019. Open Access. This article is distributed under the terms of the Creative Commons Attribution 4.0 International License which permits unrestricted use, sharing, distribution, and reproduction in any medium, provided you give appropriate credit to the original author(s) and the source, provide a link to the Creative Commons license, and indicate if changes were made. 


\section{INTRODUCTION}

Pneumonia is one of the famous diseases of cattle and calves. It causes severe economic losses, including weight loss, feed loss, significant morbidity and mortality, neglected and underdeveloped animals, as well as the costs of treatment and early unwanted exclusion (such as death, euthanasia or slaughter) ${ }^{1-5}$.

Respiratory diseases and mainly pneumonia are caused by different agents including biological, chemical, and physical agents. The biological agents include viruses, bacteria, Mycoplasma, fungi, protozoa and parasites ${ }^{2,4}$.

Mycoplasmas are one of the principal causes of diseases in the respiratory system and other organs, and include lots of species like Mycoplasma mycoides subsp. mycoides, $M$. bovis, Mycoplasma agalactiae, Mycoplasma dispar, Mycoplasma californicum, Mycoplasma canis, Mycoplasma alkalescens, Mycoplasma arginini, Mycoplasma bovirhinis, Mycoplasma bovigenitalium, Mycoplasma bovoculi, ....ext. ${ }^{4,6}$.

Mycoplasma bovis is a principal pathogen of cattle and calves, and cause many infections in calves including pneumonia, arthritis, , and conjunctivitis ${ }^{1,7-10}$. So the targeted of the current study was diagnosis Mycoplasma mainly M. bovis from an outbreak of pneumonia in calves.

\section{MATERIALS AND METHODS} Samples

Lung samples were collected from fortytwo slaughtered and dead pneumonic calves during an outbreak that occurred in Mosul city and mainly in Gogjaly village during the period of January-February/2019. The diseased calves were distributed in seven herds, the calves' numbers in these herds were ranged between (27-62 calves). The clinical signs and necropsy findings were recorded. The samples under cooling condition were transported to Microbiology and PCR laboratories at department of MicrobiologyCollege of Veterinary Medicine/ University of Mosul, and saved under refrigeration till used. All the samples were undergone to extraction and amplification.

\section{DNA extraction and Amplification}

The DNA extraction was performed according to manufacturer instructions (gSYNC ${ }^{\text {TM }}$ Geneaid extraction kit): Lung samples were collected and prepared as described by ${ }^{11}$. They were collected in the plastic container and stored at $-80^{\circ} \mathrm{C}$ until use. Lung tissue $(25 \mathrm{mg})$ was macerated in a $1.5 \mathrm{ml}$ microcentrifuge tube with a pestle. To each sample, both of $200 \mu \mathrm{l}$ GST buffer solution and $20 \mu$ lof Proteinase-K were added. Samples were vortex thoroughly for 10 seconds and incubated at $60^{\circ} \mathrm{C}$ overnight. Dissolved samples were centrifuged at $16000 \mathrm{xg}$ for $2 \mathrm{~min}$, the supernatant was collected in new $1.5 \mathrm{ml}$ tube, then $200 \mu \mathrm{l}$ of GSB was added to the supernatant, again it was a vortex for $10 \mathrm{sec}$. $200 \mu \mathrm{l}$ absolute ethanol was added to the lysate sample and mixed well via vortex. All mixtures were transferred to GS columns and centrifuged


W2 $(600 \mu l)$ buffers were added respectively to GS column with centrifugation. Finally $100 \mu \mathrm{l}$ of preheated elution buffer was added to each tube to elute the purified DNA, and stored at $-20^{\circ} \mathrm{C}$ until used.

Two pairs of primers Table 1 were synthesized by BIONEER Co. (Korea) according to ${ }^{12-}$ ${ }^{13}$ for detecting the targeted genus Mycoplasma and species $M$. bovis. PCR reaction was done in $25 \mu \mathrm{l}$ as in Table 2. The amplification program was performed depending on the instructions as in Table 3.

Table 1. Primers used to detect Mycoplasma genus and M. bovis strains

\begin{tabular}{lccc}
\hline Primer & Sequence (5'-3') Product & $\begin{array}{c}\text { Molecular } \\
\text { weight }\end{array}$ \\
\hline $\begin{array}{l}\text { Detection of } \\
\text { Genus }\end{array}$ & MYCO.-F & GGG-AGC-AAA-CAC-GAT-AGA-TAC-CCT & $285 \mathrm{bp}$. \\
$\begin{array}{l}\text { Mycoplasma } \\
\text { Detection of }\end{array}$ & MYCO.-R & TGC-ACC-ATC-TGT-CAC-TCT-GTT-ACC-CTC & \\
$\begin{array}{l}\text { B. bovis } \\
\text { BOVIS.-F }\end{array}$ & ATA-TTG-AAA-AAG-TTA-TAT & $232 \mathrm{bp}$. \\
\hline
\end{tabular}


Table 2. Final PCR buffer total volume $25 \mu \mathrm{l}$

\begin{tabular}{lc}
\hline Mixture & $\begin{array}{c}\text { Volume per reaction } \\
\text { (final conc.) }\end{array}$ \\
\hline PCR gradient water & $6.5 \mu \mathrm{l}$ \\
2.5X Master Mix & $10 \mu \mathrm{l}(2.5 \mathrm{X})$ \\
Primer F $(10 \mu \mathrm{M})$ & $1 \mu \mathrm{l}(0.4 \mu \mathrm{M})$ \\
Primer R $(10 \mu \mathrm{M})$ & $1 \mu \mathrm{l}(0.4 \mu \mathrm{M})$ \\
Extracted DNA & $5 \mu \mathrm{l}$ \\
MgCl2 & 1.5 \\
Total Volume & $25 \mu \mathrm{l}$ \\
\hline
\end{tabular}

All PCR products were analyzed by gel electrophoresis $2 \%$ agarose (Biometra, Germany), containing $0.8 \mu$ l ethidium bromide in TBE buffer. DNA bands were visualized over a UV transilluminator.

\section{RESULTS}

All infected calves were suffered from pneumonic signs that included labored breathing, fever, tachypnea, frothy salivation. Morbidity rates ranged between (8-15\%) and the mortality rates were about (15-34\%). In necropsy findings, the main lesions recorded were congestion, disseminating caseous nodules on the surface of lungs, marble appearance, hepatization (Fig. 1), and in some slaughtered calves, the lungs had a putrefied bad odor with ulceration on surface. The results of amplification appeared that $37(88.1 \%)$ samples were positive for Mycoplasma (Table 4, fig. 4), and M. bovis appeared in 32 (86.5\%) samples from these positive lungs (Table 4, fig. 5).

Table 3. Thermocycler program for detection of Mycoplasma and M. bovis

\begin{tabular}{lcccc}
\hline Cycle & $\begin{array}{c}\text { Temp. }{ }^{\circ} \text { C for } \\
\text { Mycoplasma }\end{array}$ & $\begin{array}{c}\text { Temp. }{ }^{\circ} \text { C for } \\
\text { M. bovis }\end{array}$ & Time & Stage \\
\hline 1 & 95 & 95 & 5 min. & $\begin{array}{c}\text { Initial DNA } \\
\text { denaturation } \\
\text { DNA denaturation }\end{array}$ \\
30 & 95 & 95 & 20 sec. & Primer annealing \\
& 59 & 40 & 30 sec. & Primer extension \\
1 & 72 & 72 & 30 sec. & Final extension \\
1 & 72 & 72 & 5 min. & Cooling \\
\hline
\end{tabular}
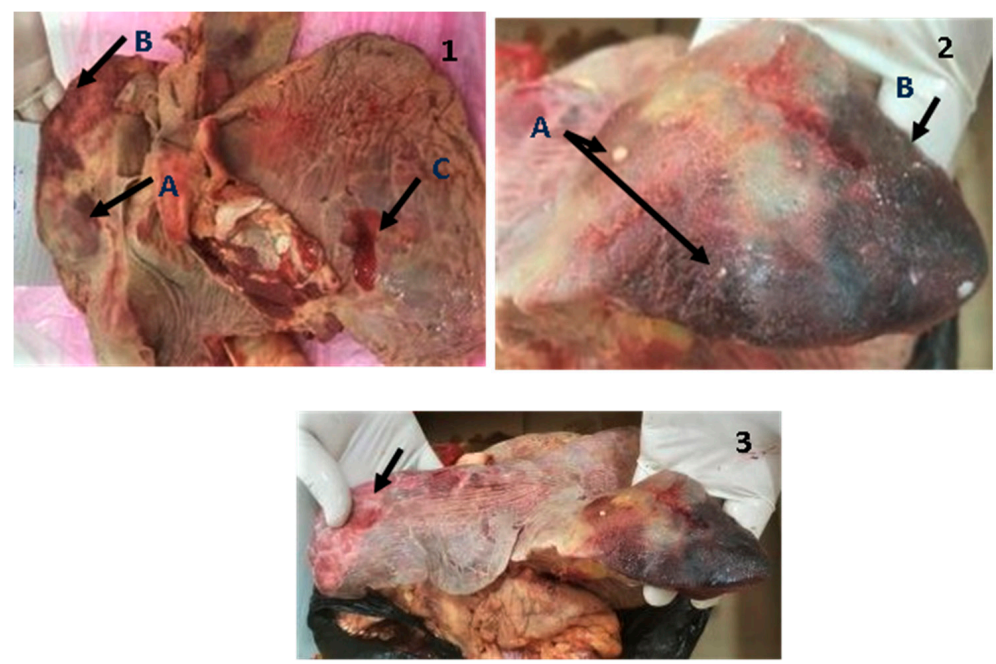

Fig. 1-3. Lung suspected to be infected with bovine mycoplasmosis.

1(A: Caseous nodules, B: Congestion, C: Ulceration), 2 (A: Caseous nodules, B: Hepatization), 3(Marbling Appearance) 


\section{DISCUSSION}

Mycoplasma bovis is a principal pathogen of respiratory diseases and mainly pneumonia in calves, and causes heavy economic losses in the cattle industry which may reach up to the third of losses that correlated to respiratory infections ${ }^{1,9,14}$.

The present study was targeted to diagnose the Mycoplasma, principally $M$. bovis from an outbreak of pneumonia in calves. So the results of the study recorded an excessive presence of Mycoplasma (88.1\%) in samples of pneumonic calves, and $M$. bovis has appeared in $86.5 \%$ of these positive samples. The Mycoplasma rates and especially $M$. bovis excessive and terrible, and should care about especially when it a companied by considerable Morbidity (8-15\%) and Mortality rates (15-34\%) with the knowledge that it appears as a resistant pathogen for several antimicrobials ${ }^{15-19}$, where one study reported that the increase in deaths of calves due to respiratory disease from an average $9.7 \%$ per year to $36.5 \%$ per year communicated with the isolation of $M$. bovis from the lungs ${ }^{20}$.

Table 4. Prevalence of Mycoplasma and M. bovis detected in pneumonic calves lung

\begin{tabular}{lccccc}
\hline $\begin{array}{l}\text { No. } \\
\text { Lungs }\end{array}$ & Mycoplasma & $\%$ & $\begin{array}{c}M . \\
\text { bovis }\end{array}$ & $\%$ & $\%$ \\
\hline 42 & 37 & 88.1 & 32 & $86.5 *$ & $76.2 * *$ \\
\hline
\end{tabular}

* Rate of $M$. bovis from the positive Mycoplasmal samples

** Rate of $M$. bovis from the total lungs samples
Although there were no local studies about Mycoplasma and M. bovis in pneumonic cases for comparing, lots of studies worldwide diagnosed and/or isolated these microorganisms in high or considerable rates from pneumonia in calves. One of these studies which concurred the current results is a Turkish study ${ }^{21}$ revealed that $80.9 \%$ of examined herds were positive for Mycoplasma infection and $87.6 \%$ of isolates were $M$. bovis. Another research in France $^{22}$ was diagnosed $M$. bovis in $78.5 \%$ of feedlot calves that were suffered from respiratory signs, while in more recently French study ${ }^{23}$ the rate of isolation of $M$. bovis from cases of bovine respiratory disease was about $12-18 \%$ and it constituted about $55 \%$ of all isolated Mycoplasma from different pathogenic cases in cattle, whearas thorough investigation in feedlots in France ${ }^{24}$, one M. bovis strain turns out to be prevalent via the fattening stage and was accountable for shrill epidemics of bovine respiratory disease (BRD) with excessive insidegroup pervasiveness. Whilst in the Netherlands M. bovis was found in $20 \%$ of pneumonic calves in fattening flocks, though it found in very little rate in healthy calves $(3 \%)^{25-26}$, and in a recent Dutch study ${ }^{17}$ the lung isolates from $M$. bovis accounted about $58.5 \%$ of all $M$. bovis isolates diagnosed from a different infection during 20082014. Also, a study in Denmark was reported that $86 \%$ of pneumonic lungs found infected with mycoplasmas, and $M$. bovis appeared in $24 \%$ of these lungs ${ }^{27}$. Whereas Tschopp et al.,

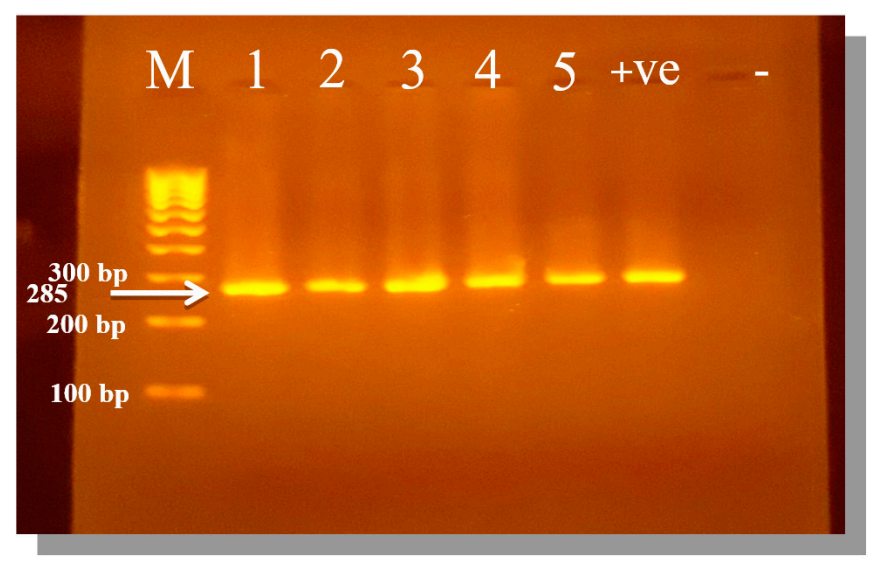

Fig. 4. PCR amplification products of Mycoplasma gene on $2 \%$ agarose gel.

M: Marker (100-1000 bp), samples (1 - 5): positive for genus Mycoplasma At 285 bp. molecular weight, +ve: Control positive for genus Mycoplasma, -ve: Control negative for genus Mycoplasma. 


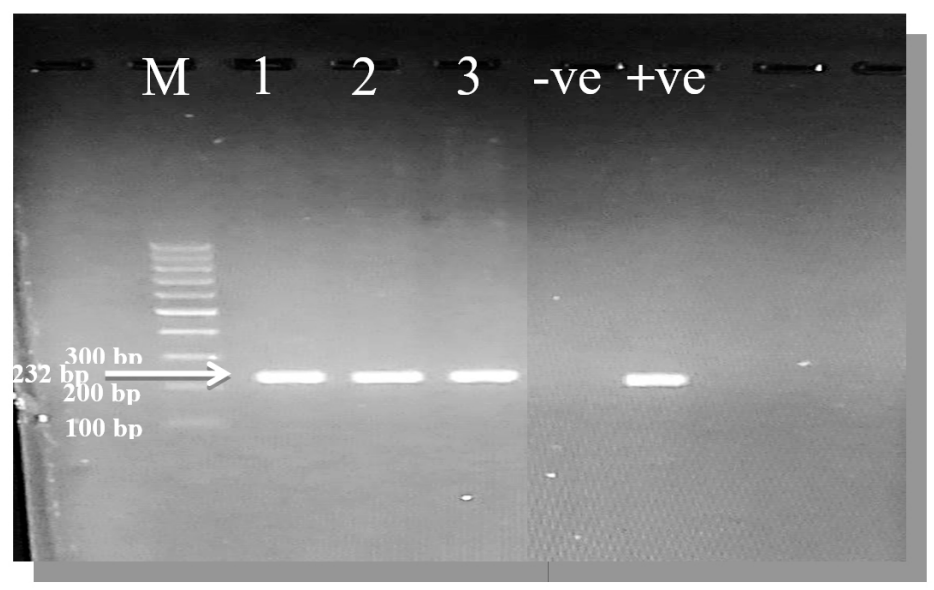

Fig. 5. PCR amplification products of Mycoplasma bovis gene on $2 \%$ agarose gel. M: Marker (100-1000 bp), samples (1 - 5): positive for M. bovis At 232 bp. molecular weight, +ve: Control positive for $M$. bovis, -ve: Control negative for M. bovis.

$2001^{28}$ inspected pneumonia in feedlot calves and stated that $50.3 \%$ of obivious respiratory attacks were attributed to $M$. bovis. In Belgium, a study rumored the acute and recurrent respiratory cases and showed the isolation of Mycoplasmas from $78 \%$ of calves undergoing recurrent respiratory infection and from $65 \%$ of acute pneumonia infections. $M$. bovis was presence in $35 \%$ of calves suffering from recurrent respiratory infection, and from $50 \%$ of acute infections ${ }^{29}$. While in a recent Belgian study ${ }^{30}$ recorded isolation of mycoplasma species by $70.5 \%$ at the level of the individual calf, while at the herd level, the presence of $M$. bovis was detected in $84.6 \%$ of the tested herds. Also, for comparison, a Pakistani study indicated that $M$. bovis was isolated by $42 \%$ of all dead calves ( 15 calves) and lives ( 35 calves) understudy at the time $^{31}$. The main differences between the current results and the results of the global studies may be due to the differing in environmental conditions, ages of animal, the health status, feeding, and the strains of animals ${ }^{3,32-35}$, although the calves undergo the present study were from importing strain.

The results of current study showed diagnosis of $M$. bovis from $86.5 \%$ of the positive lungs for Mycoplasma, which means the presence of other Mycoplasma species (13.5\%) that may be playing a role in the occurrence of pneumonia in calves, and there are many universal studies that confirmed the presence of other Mycoplasma species excluding $M$. bovis in pneumonic calves lungs, as well as they may be isolated or were diagnosed in an excessive rates and in some times


studies reviewed no diagnosis of $M$. bovis from pneumonic infections in calves ${ }^{37-38}$.

Depending on the obtained results, the PCR technique was appeared as an excellent directly method in the diagnosis of Mycoplasma and principally $M$. bovis from pneumonic lungs, without the demands for culturing microorganism, which is accurate method and will reduce the consuming time and efforts. Many global studies supported the use of PCR instead of the culturing or together for diagnosis of Mycoplasma and particularly M. bovis ${ }^{39-45}$.

In conclusion, this study is the first local research at the moment to diagnose Mycoplasma in general and in particular M. bovis of pulmonary calves using molecular techniques. Also, according to the current results it recommends the use of PCR in the direct diagnosis of $M$. bovis from pneumonic lungs, and detect the other Mycoplasma species in pneumonic calves.

\section{ACKNOWLEDGEMENTS}

The authors thank college of the Veterinary Medicines/ University of Mosul, Iraq for their Moral support. 


\section{CONFLICTS OF INTEREST}

The authors declare that there is no conflict of interest.

\section{AUTHORS' CONTRIBUTION}

All authors listed have made a substantial, direct and intellectual contribution to the work, and approved it for publication.

\section{FUNDING}

None.

\section{DATA AVAILABILITY}

All datasets created or investigated during this study are involved in the manuscript and/or the Supplementary Files.

\section{ETHICS STATEMENT}

This article does not contain any studies with human participants or animals performed by any of the authors.

\section{REFERENCES}

1. Nicholas RA, Ayling RD. Mycoplasma bovis: disease, diagnosis, and control. Res. Vet. Sci., 2003; 74: 105-12. https://doi.org/10.1016/S0034-5288(02)00155-8

2. Radostitis OM, Gay CC, Hinchcliff KW, Constable PD. 2007. Veterinary Medicine : A textbook of the diseases of cattle, horses, Sheep, Pig \& goats. Part1, PP:471$472.10^{\text {th }}$ ed, Elsevier, New York.

3. Taylor JD, Fulton RW, Lehenbauer TW, Step DL, Confer AW. The epidemiology of bovine respiratory disease: what is the evidence for predisposing factors?. Can. Vet. J., 2010; 51: 1095-1102.

4. Quinn PJ, Markey BK, Leonard FC, Fitz Patric ES, Fanning S, Hartigan PJ. Veterinary Microbiology \& Microbial disease, 2011; 67-69. 2nd ed. UK. WiLey-Blackwell.

5. Petersen MB, Ersboll AK, Krogh K, Nielsen LR. Increased incidence rate of undesired early heifer departure in Mycoplasma bovis-antibody positive Danish dairy cattle herds. Prevent Vet. Med., 2019; 166: 86-92. https://doi.org/10.1016/j.prevetmed.2019.03.013

6. Maunsell FP, Donovan GA. Mycoplasma bovis Infections in young calves. Vet. Clin. North Am. Food Anim. Pract., 2009; 25(1): 139-177. https://doi. org/10.1016/j.cvfa.2008.10.011

7. Pfutzner H, Sachse K. Mycoplasma bovis as an agent of mastitis, pneumonia, arthritis and genital disorders in cattle, Rev. Sci. Tech., 1996; 15: 1477-1494. https:// doi.org/10.20506/rst.15.4.987

8. Eissa SI, Hassan AM, Hashem YM, Shaker MM Comparative molecular study of Mycoplasma bovis isolates from Egyptian buffaloes and cows suffered from mastitis. Europ. J. of Biol. Sci., 2012; 4(4): 114120.

9. Aebi M, Borne HP, Raemy A, Steiner A, Pilo P, Bodmer
M. Mycoplasma bovis infections in Swiss dairy cattle: A clinical investigation. Acta Veterinaria Scandinavica, 2015; 57(10): 1-11. https://doi.org/10.1186/s13028015-0099-x

10. Abdeen EE, Mousa WS, and Suelam II. Genotyping of Mycoplasma bovis isolated from cattle suffering from respiratory manifestation in Menofia Province, Egypt. Pak. Vet. J., 2017; 37(1): 69-72.

11. Santos EM, Paula JFR, Motta PMC, Heinemann MB, Leite RC, Haddad JPA, Del Puerto HL, Reis JKP. Comparison of three methods of DNA extraction from peripheral blood mononuclear cells and lung fragments of equines, Gene and Mol. Res., 2010; 9(3): 1591-1598. https://doi.org/10.4238/vol9-3gmr818

12. Aghabalaei E, Hedayati M H, Shapouri R, Ghorbani $M$, Nejati $M$ Sadati $M$ and Ahmadi $H$. Detection of Urogenital Mycoplasmas using Culture and PCR, Journal of Advances in Bioresearch SOE, 2012; 3(4): 181- 184.

13. Maunsell FP, Woolums AR, Francoz D, Rosenbusch RF, Step D L, Wilson DJ, and Janzen ED. Mycoplasma bovis infections in cattle. Journal of veterinary internal medicine / American College of Veterinary Internal Medicine, 2011; 25(4): 772-83. https://doi. org/10.1111/j.1939-1676.2011.0750.x

14. Yilmaz R, Cangul I T, Onat K, Akkoc A, Ozyigit M O, Akdesir E. Histopathological, mmunohisto-chemical and bacteriological characterization of Mycoplasma bovis pneumonia in cattle. Pak. Vet. J., 2016; 36:31621.

15. Hendrick SH, Bateman KG, Rosengren LB. The effect of antimicrobial treatment and preventive strategies on bovine respiratory disease and genetic relatedness and antimicrobial resistance of Mycoplasma bovis isolates in a western Canadian feedlot. Can. Vet. J., 2015; 54: 1146-1156.

16. Gautier-Bouchardon AV, Ferre S, Le Grand D, Paoli A, Gay E, Poumarat F. Overall decrease in the susceptibility of Mycoplasma bovis to antimicrobials over the past 30 years in France. PLOS ONE, 2014; 9(2):e87672. https:// doi.org/10.1371/journal.pone.0087672

17. Heuvelink A, Reugebrink C, Mars J. Antimicrobial susceptibility of Mycoplasma bovis isolates from veal calves and dairy cattle in the Netherlands. Vet. Microb., 2016; 189: 1-7. https://doi.org/10.1016/j. vetmic.2016.04.012

18. Lysnyansky I, Ayling RD. Mycoplasma bovis: mechanisms of resistance and trends in antimicrobial susceptibility. Front. Microbiol., 2016;7:595. https:// doi.org/10.3389/fmicb.2016.00595

19. Sulyok KM, Beko K, Kreizinger Z, Wehmann E, Gyuranecz M. Development of molecular methods for the rapid detection of antibiotic susceptibility of Mycoplasma bovis. Vet. Microb., 2018; 213: 47-57. https://doi.org/10.1016/j.vetmic.2017.11.026

20. Gourlay RN, Thomas LH, Wyld SG. Increased severity of calf pneumonia associated with the appearance of Mycoplasma bovis in a rearing herd. The Vet. Rec., 1989; 124(16): 420-422. https://doi.org/10.1136/ vr.124.16.420

21. Sayin Z, Sakmanoglu A, Ucan US, Uslu A, Hadimli $\mathrm{HH}$, Zeki Aras Z, Ozdemir O, Erganis O. Mycoplasma 
infections in dairy cattle farms in Turkey. Turk. J. Vet. Anim. Sci., 2016; 40: 569-574. https://doi. org/10.3906/vet-1602-82

22. Arcangioli MA, Duet A, Meyer G, Dernburg A, Bezille P, Poumarat F, Le Grand D. The role of Mycoplasma bovis in bovine respiratory disease outbreaks in veal calf feedlots. Vet. J., 2008; 177: 89-93. https://doi. org/10.1016/j.tvjl.2007.03.008

23. Chazel M, Tardy F, Le Grand D, Calavas D, Poumarat F. Mycoplasmoses of ruminants in France. Recent data from the national surveillance network. BMC Vet. Res., 2010; 6: 32. https://doi.org/10.1186/1746-6148-6-32

24. Timsit E, Arcangioli MA, Bareille N, Seegers H, Assie S. Transmission dynamics of Mycoplasma bovis in newly received beef bulls at fattening operations. J. Vet. Diagn. Invest., 2012; 24: 1172-6. https://doi. org/10.1177/1040638712463211

25. Ter Laak EA, Noordergraaf JH, Boomsluiter E. The nasal mycoplasmal flora of healthy calves and cows. Zentralb/ Veterinarmed B, 1992a; 39(8): 610-6. https:// doi.org/10.1111/j.1439-0450.1992.tb01212.x

26. Ter Laak EA, Noordergraaf JH, Dieltjes RP. Prevalence of mycoplasmas in the respiratory tracts of pneumonic calves. Zentralb/ Veterinarmed B, 1992b; 39(8): 553-62. https://doi.org/10.1111/j.1439-0450.1992.tb01205.x

27. Kusiluka LJ, Ojeniyi B, Friis NF. Increasing prevalence of Mycoplasma bovis in Danish cattle. Acta Veterinaria Scandinavica, 2000; 41(2): 139-146.

28. Tschopp R, Bonnemain P, Nicolet J, Burnens A. Epidemiological study of risk factors for Mycoplasma bovis infections in fattening calves. Schweiz Arch Tierheilkd, 2001; 143: 461-7.

29. Thomas A, Ball H, Dizier I, Trolin A, Bell C, Mainil J, Linden A. Isolation of mycoplasma species from the lower respiratory tract of healthy cattle and cattle with respiratory disease in Belgium. Vet. Rec., 2002; 151(16): 472-6. https://doi.org/10.1136/vr.151.16.472

30. Pardon B, De Bleecker K, Dewulf J, Callens J, Boyen F, Catry B, Deprez P. Prevalence of respiratory pathogens in diseased, non-vaccinated, routinely medicated veal calves. Vet. Rec., 2011; 169(11): 278. https://doi. org/10.1136/vr.d4406

31. Mahmood F, Khan A, Hussain R, Khan IA, Younus M. Patho-bacteriological investigation of an outbreak of Mycoplasma bovis infection in calves -Emerging stealth assault. Microbial Pathogenesis, 2017; 107: 404-408. https://doi.org/10.1016/j.micpath.2017.04.003

32. Griffin D, Chengappa MM, Kuszak J, McVey DS. Bacterial pathogens of the bovine respiratory disease complex. Vet. Clin. North Am. Food Anim. Pract., 2010; 26(2): 381-94. https://doi.org/10.1016/j.cvfa.2010.04.004

33. Nicholas RA. Bovine mycoplasmosis: silent and deadly. Vet. Rec., 2011; 168: 459-462. https://doi. org/10.1136/vr.d2468

34. Becker CAM, Thibault FM, Arcangioli MA, Tardy F. Loss of diversity within Mycoplasma bovis isolates collected in France from bovines with respiratory diseases over the last 35 years. Infect. Genet. Evol., 2015; 33: 118-26. https://doi.org/10.1016/j.meegid.2015.04.019

35. Schibrowski ML, Gibson JS, Hay KE, Mahony TJ, and
Barnes TS. Mycoplasma bovis and bovine respiratory disease: A risk factor study in Australian feeder cattle. Preventive Veterinary Medicine, 2018; 157(1): 152-161. https://doi.org/10.1016/j.prevetmed.2018.06.005

36. Kumar A, Verma AK, Gangwar NK, Rahal A. Isolation, Characterization, and Antibiogram of Mycoplasma bovis in Sheep Pneumonia. Asian Journal of Animal and Veterinary Advances, 2012; 7(2): 149- 157. https:// doi.org/10.3923/ajava.2012.149.157

37. Autio $T$, Pohjanvirta $T$, Holopainen R, Rikula $U$, Pentikainen J, Huovilainen A, Rusanen H, Soveri T, Sihvonen L, Pelkonen S. Etiology of respiratory disease in non-vaccinated, non-medicated calves in rearing herds. Vet. Microbiol., 2007; 31; 119(2-4): 256-65. https://doi.org/10.1016/j.vetmic.2006.10.001

38. Angen O, Thomsen J, Larsen LE, Larsen J, Kokotovic B, Heegaard PM, Enemark JM. Respiratory disease in calves: microbiological investigations on transtracheally aspirated bronchoalveolar fluid and acute phase protein response. Vet. Microbiol.,2009; 137(1-2): 165-71. https://doi.org/10.1016/j.vetmic.2008.12.024

39. Sachse K, Pfutzner H, Hotzel H, Demuth B, Heller M, Berthold E. Comparison of various diagnostic methods for the detection of Mycoplasma bovis. Rev. Sci. Tech., 1993; 12(2): 571-80. https://doi.org/10.20506/ rst.12.2.701

40. Judit B, Noemi E, Zsuzsanna S, Stipkovits L. Detection of Mycoplasma bovis by different PCR systems. Magyar Allatorvosok Lapja, 2004; 126(10): 626-630.

41. Cremonesi P, Vimercati C, Pisoni G, Perez G, Ribera MA, Castiglioni B, Luzzana M, Ruffo G, Moroni P. Development of DNA Extraction and PCR Amplification Protocols for Detection of Mycoplasma bovis Directly from Milk Samples. Vet Res Commun, 2007; 31(1): 225-227. https://doi.org/10.1007/s11259-007-0011-x

42. Naikare H, Bruno D, Mahapatra D, Reinisch A, Raleigh R, Sprowls R . Development and Evaluation of a Novel Taqman Real-Time PCR Assay for Rapid Detection of Mycoplasma bovis: Comparison of Assay Performance with a Conventional PCR Assay and Another Taqman Real-Time PCR Assay. Vet. Sci., 2015; 2: 32-42. https:// doi.org/10.3390/vetsci2010032

43. Parker AM, House JK, Hazelton MS, Bosward KL, Sheehy PA. Comparison of culture and a multiplex probe PCR for identifying Mycoplasma species in bovine milk, semen and swab samples. PLOS ONE, 2017; 12(3): e0173422. https://doi.org/10.1371/journal. pone. 0173422

44. Manzi MP, Joaquim SF, Guimaraes FF, BruderNascimento ACMO, Pantoja JCF, and Langoni $\mathrm{H}$. Prevalence of Mycoplasma bovis in dairy herds. Pesq. Vet. Bras., 2018; 38(4): 665-669. https://doi. org/10.1590/1678-5150-pvb-5192

45. Vahanikkila N, Pohjanvirta T, Haapala V, Simojoki H, Soveri T, Browning GF, Pelkonen S, Wawegama NK, Autio T. Characterisation of the course of Mycoplasma bovis infection in naturally infected dairy herds. Vet. Microbiol., 2019; 231: 107-115. https://doi. org/10.1016/j.vetmic.2019.03.007 